\title{
Promoting Diversity and Pluralism in Contemporary Communication Policies in the United States and the United Kingdom
}

\author{
Des Freedman \\ Goldsmiths College, University of London, United Kingdom
}

\begin{abstract}
Recent revisions of media regulation and legislation have emphasized diversity and pluralism as key objectives. Both the Federal Communication Commission's rewriting of broadcasting ownership rules in 2003 and the United Kingdom government's 2003 Communications Act insist that the public interest is best met through providing a dynamic, market-led approach to communications regulation. This article highlights definitions of diversity and pluralism that are increasingly ubiquitous in legislative and regulatory instruments that seek to "modernize" media systems in our present "communications cornucopia." This approach involves conceptualizing media diversity and media pluralism as twin outcomes of strategies designed to maximize consumer choice and market competition. The article argues that we need to challenge the assumption that meaningful forms of diversity can be brought forth only through market structures and questions the validity of quantitative assessments of media sectors that equate choice and competition with diversity. The article suggests that we need to win back a notion of diversity that is based on citizens' engagement with and interrogation of the world rather than the idea that diversity can be measured simply through the number of organizations and channels in the contemporary media environment.
\end{abstract}

Contemporary media and communications policies currently being drawn up to confront the challenges of convergence and globalization are littered with positive references to diversity and pluralism. These twin objectivesconcerned with fostering a wide range of voices in the public sphere-are key justifications for the rewriting of rules affecting the media industries at the start of the 21st century. There are, for example, 35 mentions of pluralism and 42 of diversity in the British government's communications white paper (DTI/DCMS, 2000) that underpinned the 2003 Communications Act; there are 67 mentions of pluralism and 24 of diversity in its consultation on media ownership rules (DTI/DCMS, 2001); and there are an impressive 599 references to diversity in the U.S. Federal Communications Commission's (FCC) review on broadcast ownership rules (Federal Communications Commission, 2003a) that recommended raising the national television ownership cap from $35 \%$ to $45 \%$ of the total audience.

Address correspondence to Des Freedman, University of London, Department of Media and Communications, Goldsmiths College, New Cross, London, SE14 6NW UK. E-mail: d.freedman@gold.ac.uk
These references to diversity and pluralism feature in policy documents that are highly deregulatory and liberalizing in character, relaxing media ownership restrictions and increasing the relevance of competition legislation to the media industries. Indeed, some of the strongest supporters of market liberalization insist that they are motivated by the desire to increase diversity. FCC chairman Michael Powell introduced the broadcast ownership review by claiming that the revised rules would "promote and protect diversity, competition and localism in the 21st century broadcast media marketplace" (Federal Communications Commission, 2003b, p. 1). The Italian minister for communications, Maurizio Gasparri, has described the controversial bill that consolidates prime minister Berlusconi's control of Italian television as a law that "provides for greater plurality" (Ministry of Communications, 2004). Rupert Murdoch (1998) himself claimed that his News Corporation empire plays a key role in fostering diversity, arguing that

we are a relatively small part of an ever-widening rainbow of outlets for the dissemination of diverse views. The media sector is experiencing an historic growth spurt. Plural- 
ism and diversity are growing organically under our very noses while we agonize about their shrinkage.

This is all highly confusing. Policies designed to maximize pluralism and diversity have traditionally been introduced specifically because of the perceived inability of market forces to allow a wide range of outlets to articulate a wide range of opinions to a wide range of audiences. Now it appears that market forces are seen as not only not inimical to diversity and pluralism but as the main guarantors of such aspirations. This involves a process of conceptualizing media diversity and media pluralism as twin outcomes of strategies designed to maximize consumer choice and market competition. This article seeks to assess the significance of references to diversity and pluralism that saturate contemporary communications policies and proposes a definition of media diversity that adds a new focus on disagreement to the existing emphasis on difference and choice.

\section{Defining Media Diversity and Pluralism}

According to an influential commentator on British media policy, "[n]otions of pluralism, diversity and the marketplace for ideas are at best vague and malleable, at worst adjusted to the purpose of whoever invokes them" (Tambini, 2001, p. 26). Writing about U.S. communications policy, Philip Napoli (2001, p. 126) argued that "policymakers and policy analysts have yet to reach a consensus in terms of what constitutes an adequate definition or measure of this rather ambiguous concept." For these reasons alone, it is worth attempting to untangle these terms so that we may more effectively confront the objectives of the policy regimes in which they are heavily implicated.

Diversity and pluralism are frequently used either consecutively or interchangeably in many discussions of media performance and policy. One concise definition (pertaining to both) argues the following:

\footnotetext{
Pluralism is generally associated with diversity in the media; the presence of a number of different and independent voices, and of different political opinions and representations of culture within the media. Citizens expect and need a diversity and plurality of media content and media sources. (Doyle, 2002, pp. 11-12)
}

This highlights the key issues-of the democratic requirement for contrasting sources, ideas, forms, and images present in the media environment-but does little to clarify the distinction between the two terms. The confusion is not helped by the fact that U.S. media policy debates generally focus on securing diversity whereas European ones are increasingly coalescing around the objective of pluralism (which, as we shall see, is itself closer to what U.S. policymakers describe as competition).

Denis McQuail (1992) offered a useful way of understanding the relation between the two terms. Pluralism refers to a political conception of independence from the state combined with vigorous competition for the allocation of resources. A pluralistic, competitive media system is a prerequisite for media diversity, understood as the "variability of mass media (sources, channels, messages and audiences) in terms of relevant differences in society (political, geographical, social-cultural, etc.)" (McQuail, 1992, p. 147). A plural media should fully reflect contrasting voices and interests in society, provide access to the channels that do this, and offer a full menu of products and services to audiences (McQuail, 1992). Diversity is therefore related to the media's ability to acknowledge and express existing social differences through maximizing the choices offered to audiences who are in turn able to take advantage of this provision.

Policies designed to facilitate pluralism and diversity reflect contrasting perspectives of how much diversity and plurality is currently on offer in contemporary media systems. According to Benjamin Compaine (2001), market liberalism has led to a situation where media concentration is not a significant problem and where the "democracy of the marketplace may be flawed but it is, if anything, getting better, not worse." Existing de-regulatory and liberalizing policy approaches combined with the pace of technological innovation are set to guarantee consumer choice. In vigorous opposition to this, Robert McChesney (2004) argued that it is the profit-driven nature of the commercial media that is the "problem," delivering "hyper-commercialism," partisan news, and helping to de-politicize audiences. Far from being the product of systematic deregulation, media markets were founded and sustained by probusiness government intervention and are becoming increasingly uncompetitive and undemocratic. A "democratic" solution, according to McChesney, would "necessitate a large, well-funded, structurally pluralistic, and diverse nonprofit and noncommercial media sector, as well as a more competitive and decentralized commercial sector' (p. 11). To what extent has media policy in the United States and the UK met this challenge?

In the United States, media diversity policy focuses on two interconnected phenomena. The first relates, broadly speaking, to the participation by and representation of ethnic minorities in the creative process and is part of a larger debate concerning cultural diversity that is not the prime concern of this article. The second is based on the classic liberal paradigm of media freedom in which a democratic society sustains a "marketplace of ideas." Philip Napoli (1999b) argued that this metaphor has its origins in both liberal economic and democratic theory and has competition-based as well as public good objectives. It 
is best summarized in terms of First Amendment freedoms, and, in the words of a Supreme Court judge, "rests on the assumption that the widest possible dissemination of information from diverse and antagonistic sources is essential to the welfare of the public" (quoted in Napoli, 1999b, pp. 153-154). Media diversity is therefore a key determinant of a vigorous "marketplace of ideas" through which the First Amendment is expressed and cemented and actively promoted by specific policy instruments. All major U.S. broadcast regulatory innovations, such as the Prime Time Access Rule and Fin-Syn rules (diminishing the power of the networks and promoting local and non-network programs), the Fairness Doctrine (requiring opposing views to be aired), and broadcast ownership restrictions, have been carried out under the aegis of the "marketplace of ideas" metaphor and to promote media diversity.

However, since the abolition of many of the aforementioned regulatory instruments in a de-regulatory climate, what seems to be largely underpinning the FCC's conception of diversity are beliefs in variety and competitiveness, of a smorgasbord of companies, formats, opinions, styles, niches, and narratives from which audiences are free to pick and choose. Diversity here refers not so much to what distinguishes one choice from another but to the size of the menu as a whole. It is a highly consumerist construction that privileges the act of individual selection far more than the social obligation to provide choices that are fundamentally in opposition to each other-or, in the words of the Supreme Court judge quoted earlier, viewpoints that are "antagonistic." Some regulation continues to be necessary, but it is increasingly structural rather than behavioral-maintaining some restrictions on ownership of multiple media outlets rather than positively fostering or enforcing a commitment to publicize less popular or nonconsensual viewpoints, an approach that is itself problematic in the United States because of First Amendment arguments. The protection of "viewpoint diversity," one of the core objectives of the 2003 review on broadcast ownership rules, is now to be achieved by matching consumer appetites to the instincts of the market. The effect of this policy approach-of linking increased choice to increased diversity-has been to muddy the waters between competition and diversity.

In Europe, media pluralism (rather than diversity) has become the more prevalent policy objective, but there has also been more attention aimed at highlighting the differences between the two. Pluralism gained currency in policy debates in Britain in the late 1970s (Freedman, 2003; Gibbons, 2000), a response both to the emergence of more mixed, multicultural populations as well as to increasing levels of dissatisfaction with the existing media structures. For example, the 1977 Annan Committee on the future of broadcasting articulated real concerns about the ideological narrowness of the broadcasting "duopoly" and argued that contemporary culture "is now multi-racial and pluralist...[t]he structure of broadcasting must reflect this variety" (Annan, 1977, p. 30). This laid the basis for a "pluralist" approach that sought to open up broadcasting to new and previously marginalized voices but also led to a more decentered view of broadcasting as catering to different parts of the community by increasing choice and competition-very much related to the definition of diversity discussed earlier.

This connected with the deregulatory and liberalizing initiatives of the 1980s and 1990s, where it was argued that market mechanisms together with the introduction of the new technologies of cable and satellite would expand the choices available to all audiences. Media policy was designed to facilitate the entrance of new players and outlets to media markets in an attempt to boost competitiveness and media pluralism. According to Thomas Gibbons (2000), however

media pluralism was not promoted for the purpose of supporting a more democratic role for the media, as might be supposed from its content. Instead, the idea was adopted as a transitional concept that conveniently assisted a shift from public service dominance to a market approach. (p. 307)

This new emphasis on pluralism led to a clarification of the differences between pluralism and diversity and the distinctive policy responses required by each. This was an approach in the mid-1990s closely identified with the future "New Labour" government of Tony Blair, whose political philosophy consisted of a "third way," a combination of a commitment to neo-liberal market disciplines and more traditional social democratic, welfare objectives. The Institute for Public Policy Research (IPPR) think tank, closely associated with New Labour, published the results of its investigations into the changing media in the book, New Media, New Policies (Collins \& Murroni, 1996). In the chapter on concentration of ownership, the authors distinguish between "plurality of sources and diversity of content" (Collins \& Murroni, 1996, p. 58) and claim that competition legislation, in conjunction with other regulatory instruments, is necessary to deliver plural ownership structures and a "democratic marketplace for ideas” (Collins \& Murroni, 1996, p. 63). However, although the authors argue that there is no straightforward or predictable connection between pluralism (of outlets and of ownership) and diversity (of content), their emphasis is very much on developing quantitative measures (around market share, for example) designed to produce pluralistic ownership structures in the hope that diverse content and voices will flow from this.

The incoming New Labour government adopted this approach and further specified the difference between 
pluralism and diversity in the communications white paper (DTI/DCMS, 2000) and especially in its consultation on media ownership rules (DTI/DCMS, 2001). The latter argued the following succinctly:

Diversity refers to the variety of different programmes, publications and services that are available, whereas plurality is about the choice people can make between different providers of those services. Both are key to the quality of service and the range of news and opinion we as citizens receive from the media. They are, however, delivered by different means. (DTI/DCMS, 2001, p. 6)

The traditional mechanism for ensuring media diversity is through positive content regulation, for example, public service broadcasting, independent production, local content quotas, subsidies, and statutory programming requirements (precisely the behavioral regulation that is largely absent in the United States). Pluralism, on the other hand, is delivered through competition legislation backed up by media-specific ownership restrictions that are designed to curb bottlenecks and excesses of power, to maintain entry to media markets, and to encourage competition within these markets. There is little difference between this and the fostering of competitive media markets to secure "viewpoint diversity" in the United States.

Although this is a helpful step forward in distinguishing between plurality (of sources) and diversity (of content), the underlying principles separating them are becoming less distinctive. Both objectives are now defined along familiar contours of variety and choice and both are to be realized through a combination of market forces and limited regulatory intervention. For example, according to the section on "maintaining diversity and plurality" in the UK's communications white paper, convergence has inspired companies to increase content production across a range of platforms-market forces, it argues, are already "delivering a large element of the diverse services which our society requires" (DTI/DCMS, 2000 , p. 35). We are therefore left with a situation in which the discourse of pluralism and diversity is extraordinarily common in British media policymaking, eloquently defined, clearly distinguished, but increasingly conceptualized in terms of efficiency, consumer satisfaction, and customer choice. Philip Napoli noted a similar "shift in orientation" in the United States from looking at diversity as a public good toward one that is a "tangible and empirically assessable construct” (Napoli, 1999a, p. 8), an illustration of the contemporary neo-liberal interpretation of the "marketplace of ideas" metaphor (Napoli, 1999b). It appears that, in the contemporary U.S. and UK policy arenas, the objectives of media diversity and media pluralism are converging around the rhetoric of competition and choice.

\section{Pluralism and Diversity in Media Policy Today}

A commitment to media pluralism is now at the heart of communications policy at national and supranational levels. The Council of Europe produced a recommendation in 1999 concerning measures to promote media pluralism (Council of Europe, 1999), whereas Article II-11 of the proposed European Constitution, in the section on freedom of expression and information, states that the "freedom and pluralism of the media shall be respected" (European Constitution, 2003a). The World Summit on the Information Society declared its commitment to the principles of "the independence, pluralism and diversity of media, which are essential to the Information Society" (World Summit on the Information Society, 2003, p. 8). National bargaining, however, is still vital: in its green paper on services of general interest, the European Commission admits that, despite its desire to secure media pluralism throughout the European media, "the protection of media pluralism is primarily a task for the Member States" (European Constitution, 2003b, p. 22). In Britain, this responsibility is largely overseen by the new "super-regulator" Ofcom, whose mission is to "[b]alance the promotion of choice and competition with the duty to foster plurality..." (Ofcom, 2004). On the other hand, in the United States, diversity is one of the three key policy goals (together with competition and localism) guiding the FCC's attitudes toward media ownership (see Federal Communications Commission, 2003a, p. 8).

In this situation, let us consider these two countries' approaches to securing pluralism and diversity in contemporary media systems, first via recent legislation in the UK and second via the FCC's 2003 review of broadcast ownership rules. Both case studies make it clear that the traditional justifications for seeking to foster and protect a range of voices in the media-that spectrum scarcity made regulation desirable and necessary-are no longer applicable. According to FCC chairman Michael Powell, the contemporary media environment is defined by its "abundance" which

means more programming, more choice and more control in the hands of citizens. At any given moment, our citizens have access to scores of TV networks devoted to movies, dramatic series, sports, news and educational programming, both for adults and children. In short, niche programming to satisfy almost any of our citizens' diverse tastes. (Powell, 2003, p. 4)

This is similar to the language used by British trade and culture officials, that we live in a "communications cornucopia" featuring "dramatically increased quantities of images, information and data available to us from all over the world through a widening array of everyday devices 
and networks" (DTI/DCMS, 2000, p. 7). The consequence is that diversity, although an objective to be protected and expanded, is already with us thanks to the vigor of market forces and the deployment of new technologies; it is virtually guaranteed because of the perceived pluralism of the modern media landscape. By adopting this definition of diversity, British and U.S. media markets can be seen to be relatively healthy and not overly monopolistic or exclusionary.

This conception of diversity-of a plethora of outlets, services, and audiences-is used in the British white paper far more than a definition that highlights the publicizing of contrasting and "antagonistic" ideas. This leads to a real confusion as to how diversity is to be delivered. The government makes it quite clear that diversity (as opposed to plurality) has traditionally been maintained by content regulation: "In the Communications White Paper, we set out our commitment to public service broadcasting and positive content regulation, which we believe will deliver diversity in the new competitive environment" (DTI/DCMS, 2001, p. 6 , emphasis added). Yet in that white paper, the section on public service broadcasting contains only three very slight references to diversity, whereas there are 22 mentions of diversity in the section on "maintaining diversity and plurality," which is largely concerned with the need to loosen existing ownership rules. Furthermore, the government's actual (rather than rhetorical) support for an independent and critical public service broadcaster able to pursue diverse programming is open to question after its furious attack on the $\mathrm{BBC}$ as a whole following the dispute over the corporation's coverage of government claims about weapons of mass destruction (see Robinson, 2003).

The government believes there is still a need to limit multiple and cross-media ownership, but promises that "we will be as deregulatory as possible, in the knowledge that new competition legislation should be more effective in preventing companies from abusing a dominant market position" (DTI/DCMS, 2001, p. 11). This has been dramatically illustrated in recent legislation allowing for foreign ownership of terrestrial television channels, the possibility of a single Independent Television (ITV) owner, and an ambiguous "plurality test" in the case of large newspaper mergers ultimately sanctioned by the trade and industry secretary. The implication is that diversity is, above all, to be fostered through pluralistic, competitive market arrangements.

There are exceptions to this. Diversity is also to be sought through the continuing use of quotas for independent production, through a commitment to regional broadcasting, and through exploring the possibilities for increased community broadcasting. There are, however, serious concerns about the ability of any of these developments to challenge the procompetition understanding of diversity that is increasingly hegemonic. First, the independent production sector is subject to higher levels of commercial pressure than the large public service broadcasters and was developed in the UK in the 1980s precisely to stimulate market forces inside broadcasting (see Freedman, 2003, p. 133). The government has recently introduced rules that allow independent companies to keep control of copyright in international sales in an attempt, not to promote diversity, but to build up the profitability and competitiveness of British television in general. Second, the government's commitment to regional broadcasting can be questioned by its sanctioning of mergers in the ITV sector that allow for the possibility of a single, centralized ITV system that would certainly undermine regional diversity. Finally, its support for community broadcasting in the shape of highly localized restricted service licenses in both television and radio would be a welcome boost for noncommercial voices and structures but forms a marginal part of its overall broadcasting policy.

In the United States, the FCC's 20-month review of media ownership regulation culminated in a decision in June 2003 to loosen ownership rules and sanction further cross-media ownership. The new rules allow newspapers to own television and radio stations in the same city and increase the share of the national audience that a television network may reach, from $35 \%$ to $45 \%$. This degree of liberalization was proposed despite the FCC's acknowledgment that viewpoint diversity, the desired policy objective, "is fostered when there are multiple independently owned media outlets" (Federal Communications Commission, 2003c, p. 2). ${ }^{1}$

A key way in which the FCC sought to manage the contradiction between increased diversity and reduced ownership controls is through its highly empirical understanding of diversity. The rules designed to maximize viewpoint diversity are based on a quantitative method of measuring diversity, a "Diversity Index" (DI) based on antitrust analysis of the degree of concentration in a particular economic sphere. This takes into consideration the number of different media outlets (broadcast television, radio, newspaper, and the Internet) in any one market, the number of companies (called "voices" by the FCC) in that market together with the weighting of each media sector in terms of consumer perception of their importance as a source of local news. The FCC's example of "Anytown USA" is a market (Federal Communications Commission, 2003c, pp. 9-10) in which there are 39 different media outlets, including two separate daily papers and two separate Internet providers; one company owns 2 of the 8 television stations and 3 of the 26 radio stations, whereas another company owns 6 of the 26 radio stations. This adds up to a DI rating of 738, well below the threshold of "moderate concentration" of 1000 and far below the DI of 1800, which constitutes a "highly concentrated" market.

This is a highly unsatisfactory way of assessing diversity for a number of reasons. First, market share is worked 
out simply in terms of the total number of outlets and not in terms of actual sales or ratings. This means that the market share of a community-owned or independent radio station with low audiences and minimal advertising is precisely the same as a commercial one with much larger audiences and more income. This immediately exaggerates the diversity of real markets where large radio groups such as Clear Channel will be able to use their resources and market power to exert far more influence over that locality than their "competitors." Second, the DI's quantitative methodology fails to assess the type of views that are actually expressed; there may be 26 separate radio stations but they may largely be playing to the same tune. Finally, and perhaps most importantly, the FCC's example is extremely unusual and therefore misleading: only a tiny number of cities in the United States have two separate daily newspapers, just as the existence of 18 separate radio "voices" in one area is also increasingly rare. It means ignoring markets like Mansfield, Ohio, where Clear Channel owns 11 out of the 17 radio stations, or Albany, Georgia, where Cumulus owns 8 of the 15 stations. Research carried out by the Center for Public Integrity (Dunbar \& Pilhofer, 2003) discovered large numbers of radio markets controlled by either one or two broadcast companies. This is set to increase with the liberalization of ownership rules. In summary, the index employed by the FCC is a means of measuring diversity where what is being said is entirely irrelevant, where audience share and market power is ignored, and where only the number of people speaking and the form of speech are measured.

\section{Diversity and Antagonism}

The idea that the pluralistic media systems of the United States and the UK inevitably lead to the expression of diverse views is barely credible when one examines the highly partisan coverage of, for example, the Iraq War by the U.S. media, and the only marginally less consensual coverage in the British media, where 15 out of the 17 national newspapers supported the invasion in their leader columns. Any critical reporting that did take place was more likely the result of a desire to tap into burgeoning antiwar opinion than it was the result of an intrinsically pluralistic media system. The relentless criticism of Tony Blair's support for George Bush and the invasion of Iraq in the tabloid Daily Mirror (often used to symbolize the diversity of the British press) was unprecedented but highly unstable, disappearing when there were no immediate commercial benefits. The market proved to be a very unreliable guarantor of diversity even in a situation marked by political divisions and public opposition.

Contemporary media policymakers in the United States and the UK are in danger of neutering meaningful concepts of diversity through neo-liberal reforms. Diver- sity ought not to be simply about celebrating choice and recognizing differences but acting on them, acknowledging the social, political, and economic divisions that mark contemporary life and using the media to articulate them in the hope that solutions may be identified and pursued. This requires something more than merely expanding the number of media outlets or paying lip service to cultural differences; what is needed is the integration of fundamental arguments and disagreements about key issues into the fabric of the media to realize the First Amendment commitment to publicize "diverse and antagonistic sources." Diversity need not be limited to the provision of rival views expressed under (and often artificially imposing) a consensus but should flourish by challenging consensus views about the key debates of the day.

This will require structural changes to our media systems-for example, the strengthening of ownership restrictions to prevent monopolies and the tightening of positive content rules to incorporate a wider range of sources and voices into the media system-that are precisely the opposite of those currently being implemented in the United States and the UK. However, it will also require a challenge to the pluralist belief in the efficacy of the market as a means of fostering diversity. As James Curran argued (2000)

pluralism cannot just be equated with competition. It needs to mean more than this: namely media diversity supported by an open process of contests in which different social groups have the opportunity to express divergent views and values. This broader definition implies a commitment to extending freedom of expression, broadening the basis of self-determination, and promoting equitable outcomes informed by awareness of opposed opinions and interests. (p. 138)

Existing media policy arrangements in the United States and the UK are singularly failing to achieve these outcomes. For example, Mark Cooper (2004) argued that the FCC's research that provided the justification for its DI grossly underestimates local market concentration, whereas Richard van der Wurff (2004) showed how increasing levels of "choice" (packaged as pluralism) have not led to rising levels of diversity in European media markets. The tendency, identified by the economist Harold Hotelling, that rival producers will tend to offer products of "excessive sameness," seems to be particularly apt when applied to media markets (see van Cuilenburg, 1999)-a problem exacerbated by the often limited competition in many specific media sectors. Indeed, rather than deploy instruments to realize meaningful forms of diversity, we are more likely to see policymakers and regulators pressurize and marginalize those levers (for example, the independence of public service broadcasting and the scope of positive content regulation) that have traditionally 
made important contributions to airing differences and countering hegemonic voices in the media.

\section{Conclusion}

Rules designed to liberalize U.S. and UK media environments are being introduced expressly in the name of diversity and plurality. This sleight of hand has occurred through the association of both terms by policymakers with the expansion of consumer choice in the marketplace with the result that their meanings have, to a certain extent, converged around the dynamics of competition.

The diversity that is expressed in contemporary liberalizing policy initiatives is too narrow to match up to a robust interpretation of a "marketplace of ideas." It is based, above all, on the conviction that market forces are best able to underwrite the provision of and access to different views and that regulatory intervention, although necessary to correct 'market failure,' is to be minimized and avoided where possible. It relies on a conception of diversity that focuses on maximizing the number of outlets (in European terms, pluralism; in U.S. terms, competition) and emphasizes the quantity rather than quality of the range of choices that audiences have in everyday media consumption.

Yet there remain strong concerns about levels of cross-media and multi-outlet ownership, as demonstrated by the widely supported movement against the FCC's broadcast ownership review in 2003 (see McChesney, 2004, pp. 252-297). The liberalizing initiatives discussed in this article have been perceived by many critics as a sign both of increased corporate control of the media and regulatory reluctance to overrule corporate voices and to impede market forces. In this context, appeals to both pluralism and diversity are increasingly becoming smokescreens behind which a significant restructuring and marketization of the media is taking place. It is true that substantive ownership rules alone do not provide an immediate guarantee of meaningful diversity, but without them, a free and frank discussion is unlikely to take place. Contemporary "pluralist" or "diversity-led" media policy is making even this minimal task more difficult.

An "expanded" definition of diversity refers not to the simple number of newspapers, television channels, or radio stations available, but to an understanding that media should recognize and highlight the conflicts and disagreements that pervade the world today. Prodiversity communications policy needs not just to acknowledge the existence of cultural difference and to stimulate consumer choice, but to express the profound conflicts of interest that mark our society and that shape our media systems. It will be a great loss if traditions of mediated debate, interrogation, and rebuttal are diminished and re- placed by the fetishizing of choice and competition under the labels of pluralism and diversity.

\section{Des Freedman \\ (d.freedman@gold.ac.uk)}

is Senior Lecturer in Communications and Cultural Studies in the Department of Media and Communications, Goldsmiths College, University of London. He is the author of The Television Policies of the Labour Party, 1951-2001 (Frank Cass, 2003) and co-editor of War and the Media (Sage, 2003). He is currently preparing a book on media policy and policymaking for Polity Press.

\section{Endnote}

1. The rules have since been challenged and have yet to be implemented. See Robert McChesney (2004) for a full analysis of the evolution of and mobilization against the FCC's review.

\section{References}

Annan, Lord. (chair). (1977). Report on the Committee of the Future of Broadcasting (Cmnd. 6753). London, UK: Her Majesty's Stationery Office.

Collins, R., \& Murroni, C. (1996). New media, new policies. Cambridge, UK: Polity.

Compaine, B. (2001). The myths of encroaching global media ownership. Retrieved from http://www.opendemocracy.net/debates/article8-24-87.jsp

Cooper, M. (2004, October 3). When law and social science go hand in glove-usage and importance of local and national news sources: Critical questions and answers for media market analysis. Paper presented at the Telecommunications Policy Research Conference. Retrieved January 6, 2005, from http://www.fordham .edu/images/Undergraduate/communications/Cooper\%20Paper .pdf

Council of Europe.(1999). Recommendation No.R(99)1 of the Committee of Ministers to Member States on Measures to Promote Media Pluralism. Retrieved April 19, 2004, from http://cm.coe.int/ta/rec/1999/ 99r1.htm

Curran, J. (2000). Rethinking media and democracy. In J. Curran \& M. Gurevitch (Eds.), Mass media and society (3rd ed., pp. 120-154). London: Arnold.

Doyle, G. (2002) Media ownership. London: Sage.

DTI/DCMS. (2000). A new future for communications. (White Paper, Cm 5010). London : HMSO.

DTI/DCMS. (2001). Consultation on media ownership rules. Retrieved January 15, 2002, from http://www.culture.gov.uk/NR/ rdonlyres/ef5hpjmzgmkxwij2ssrlj6otcys6e2fcngipuqidcar2lra opir7o6o sc2cjrlzlb5iqtlhqiqurbgfs5xmqrjubn2a/mediaowner ship2001.pdf 
Dunbar, J., \& Pilhofer, A. (2003). Big radio rules in small markets. Retrieved April 22, 2004, from http://www.openairwaves.org/ telecom/report.aspx?aid=63

European Constitution. (2003a). Draft treaty establishing a constitution for Europe. Retrieved April 24, 2004, from http://europa .eu.int/futurum/constitution/part1/title1/index_en.htm

European Constitution. (2003b). Green paper on services of general interest (COM(2003) 270). Retrieved April 24, 2004, from http:// europa.eu.int/eur-lex/en/com/gpr/2003/com2003_0270en01.pdf

Federal Communications Commission. (2003a). Report and order and notice of proposed rulemaking (FC 03-127). Washington, DC: Author.

Federal Communications Commission. (2003b). FCC chairman Powell launches "localism in broadcasting initiative" (press release). Washington, DC: Author.

Federal Communications Commission. (2003c). FCC sets limits on media concentration (press release). Washington, DC: Author.

Freedman, D. (2003). The television policies of the labour party. London: Frank Cass.

Gibbons, T. (2000). Pluralism, guidance and the new media. In C. Marsden (Ed.), Regulating the Global Information Society (pp. 304-315). London: Routledge.

McChesney, R. (2004). The problem of the media: U.S. communication politics in the 21st century. New York: Monthly Review Press.

McQuail, D. (1992). Media performance: Mass communication and the public interest. London, UK: Sage.

Ministry of Communications. (2004). Hon Gasparri says digital switchover inevitable, creativity will win the day (press release). Retrieved April 22, 2004, from http://www.comunicazioni.it/en/ index.php?IdPag $=4 \& \mathrm{IdCom}=150 \& A n n o=2004 \&$ Mese $=\& B 1 \mathrm{k}=$
Murdoch, R. (1998, April 6). Presentation by Rupert Murdoch to the European Audiovisual Conference. Retrieved April 22, 2004, from http://europa.eu.int/eac/speeches/murdoch_en.html

Napoli, P. (1999a). Deconstructing the diversity principle. Journal of Communication, 49(4), 7-34.

Napoli, P. (1999b). The marketplace of ideas metaphor in communications regulation. Journal of Communication, 49(4), 151-169.

Napoli, P. (2001). Foundations of communications policy. Cresskill, NJ: Hampton.

Ofcom. (2004). About Ofcom. Retrieved April 20, 2004, from http:/ www.ofcom.org.uk/about_ofcom/?a=87101

Powell, M. (2003). Statement of Chairman Michael K. Powell. Retrieved April 20, 2004, from http://hraunfoss.fcc.gov/edocs_public/ attachmatch/FCC-03-127A3.doc

Robinson, J. (2003, December 14). A stick to beat the BBC. Observer, Business Section, p. 7.

Tambini, D. (2001). Through with ownership rules? Media pluralism in the transition to digital. In D. Tambini (Ed.), Communications: Revolution and reform (pp. 21-44). London: Institute for Public Policy Research.

van Cuilenburg, J. (1999). On competition, access and diversity in media, old and new: Some remarks for communications policy in the information age. New Media and Society, 1, 183-207.

van der Wurff, R. (2004). Supplying and viewing diversity. European Journal of Communication, 19, 215-238.

World Summit on the Information Society. (2003). Declaration of principles - Building the information society: A global challenge in the new millennium. Retrieved April 22, 2004, from WSIS-03/GENEVA/ DOC/4-E, 12 December, available at http://www.itu.int/dms_ pub/itu-s/md/03/wsis/doc/S03-WSIS-DOC-0004!!MSW -E. doc 